DOI: https://doi.org/10.15407/techned2018.06 $: \underline{014}$

\title{
PROBABILISTIC PROPERTIES OF ELECTRICAL CHARACTERISTICS OF CAPACITOR CHARGE CIRCUIT WITH STOCHASTIC ACTIVE RESISTANCE
}

Journal

Publisher

ISSN

Issue

Pages
Tekhnichna elektrodynamika

Institute of Electrodynamics National Academy of Science of Ukraine 1607-7970 (print), 2218-1903 (online)

No 6, 2018 (November/December)

$14-17$

\footnotetext{
Authors

A.A. Shcherba ${ }^{1 *}$, N.I. Suprunovska ${ }^{1 * \star}$, D.S. Ivashchenko ${ }^{2}$

1 - Institute of Electrodynamics National Academy of Sciences of Ukraine,

pr. Peremohy, 56, Kyiv, 03057, Ukraine,

e-mail: iednat1@gmail.com

2 - Oracle, 1501 4th Ave, Seattle, WA 98101, US,

e-mail: ivas-90@mail.ru

* ORCID ID : http://orcid.org/0000-0002-0200-369X

** ORCID ID : http://orcid.org/0000-0001-7499-9142
}

\begin{abstract}
The approach to the determination of the probability properties (probability density function, probability distribution function, mathematical expectation) of the electrical characteristics of the circuits of electric discharge installations whose active resistance can be changed at random is proposed. It is assumed that such a stochastic resistance is characterized by a continuous random variable whose probabilistic properties are known. As an example, probabilistic
\end{abstract}


properties of the voltage on a capacitor in a first-order circuit with a stochastic active resistance having a uniform probability distribution were investigated. References 10, figures 3.

Key words: transient processes, stochastic resistance, random process, continuous probability distribution.

Received: 02.03 .2018

Accepted: 14.03 .2018

Published: 23.10 .2018

\section{References}

1. Livshitz A.L., Otto M.Sh. Pulse electrotechnology. Moscow: Energoatomizdat, 1983. 352 p. (Rus)

2. Shcherba A.A., Suprunovskaya N.I., Ivashchenko D.S. Modeling of nonlinear resistance of electro-spark load taking in to account its changes during discharge current flowing in the load and at zero current in it. Tekhnicna Elektrodynamika. 2014. No 5. Pp. 23-25. (Rus)

3. Volkov I.V., Vakulenko V.M. Sources for power supply of lasers. Kiev: Tekhnika, 1976. 176

p. (Rus)

4. Suprunovska N.I., Shcherba A.A., Ivashchenko D.S. Processes of energy exchange between nonlinear and linear links of electric equivalent circuit of supercapacitors. Tekhnichna Electrodynamika . 2015. No 5. Pp. 3-11. (Rus)

5. Vovchenko A.I., Tertilov R.V. Synthesis of capacitive non-linear- parametrical energy sources for discharge-pulse technologies. Zbirnyk naukovyh pratz Natsionalnogo universytetu korablebuduvannya 118-124. (Rus)

. Mykolaiv, 2010. No 4. Pp.

6. Ivashchenko D.S., Suprunovska N.I. Transients in circuits with stochastic load, which 
characterized by continuous random variable. Tekhnichna Elektrodynamika. 2016. No 4. Pp. 17 - 19. (Rus) DOI:

tps://doi.org/10.15407/techned2016.04.017

7. Lisyev V.P. Probability theory and the mathematical statistics. Moscow: MESI, 2006. 199 p. (Rus)

8. Ventsel E.S., Ovcharov L.A. Probability theory and its engineering applications. Moscow: Vysshaya shkola, 2000. 480 p. (Rus)

9. Kash'yap R.L., Rao A.R. Construction of dynamic stochastic models based on experimental data. Moscow: Nauka. Glavnaya redaktsiya fiziko-matematicheskoy literatury, 1983. 384 p. (Rus)

10. Demirchyan K.S., Nejman L.R., Korovkin N.V., Chechurin V.L. Electrical engineering theory. Vol. 2. Saint-Petersburg: Piter, 2003. 576 p. (Rus) 